\title{
Social problems and threats in Siedlce County at the beginning of the $21^{\text {st }}$ century
}

ooking back, in the $19^{\text {th }}$ century, in the early $20^{\text {th }}$ century, maybe even until the mid- $20^{\text {th }}$ century, the biggest social problems and threats among peasants were the lack of land or owingan insufficient area of the land, overpopulation of villages, unemployment, alcoholism, illiteracy, low public awareness, and poor health care. The most important ones were the lack of land or unprofitable agricultural production. Without income, making a decent living for a family was impossible. Over the $20^{\text {th }}$ century, the situation changed. We witnessed a tremendous civilizational progress, while a development in medicine and health care programs significantly improved the quality of health and longevity. The development of educational systems, the inclusion of all children and young people into the compulsory general school education and, most of all, the expansion of schools have all contributed to increasing the social, economic and civil awareness. However, has the civilization development contributed to the elimination of all social threats and problems?

Siedlce County is a land county located in the eastern part of the Masovian Voivodeship, in the central part ofthe Eastern Wall of Poland. It covers an area of 1,603 square kilometres. ${ }^{1}$ It consists of one little town Mordy ${ }^{2}$ and 13 rural communes ( $\mathrm{gmi}$ ny), namely, Domanice, Korczew, Kotuń, Mokobody, Mordy, Paprotnia, Przesmyki, Siedlce, Skórzec, Suchożebry, Wiśniew, Wodynie and Zbuczyn. The county is inhabited by 81,375 people including 40,430 women representing $49.7 \%$ of the populationand

1 The geodetic area of the county is 160,322 ha according to EwidencjaGruntówiBudynków WydziatuGeodezjiiGospodarkiNieruchomościamiStarostwa, after: Characterisation of the county, [in:] https:// www.powiatsiedlecki.pl/charakterystyka-powiatu/ [accessed on 21.08.2017].

2 It is a small town with slightly over 2,000 inhabitants. 
40,945 men representing $50.3 \%$ of the population. ${ }^{3}$ The county surrounds the city of Siedlce, which is nonetheless a separate city county. ${ }^{4}$

Although Siedlce County and Siedlce City County are two separate territorial units, they form one civilization centre. The city of Siedlce is the main seat for the County Administrator's Office, the Siedlce land county and social organizations of the county range (e.g. County Family Support Centre, County Board of Volunteer Fire Brigades Union of Poland), or e.g. City Police Headquarters in Siedlce covers both the city of Siedlce, as well as the Siedlce land county.

On the graph below there are the number of persons employed by economic sectors in the years 2006-2016.

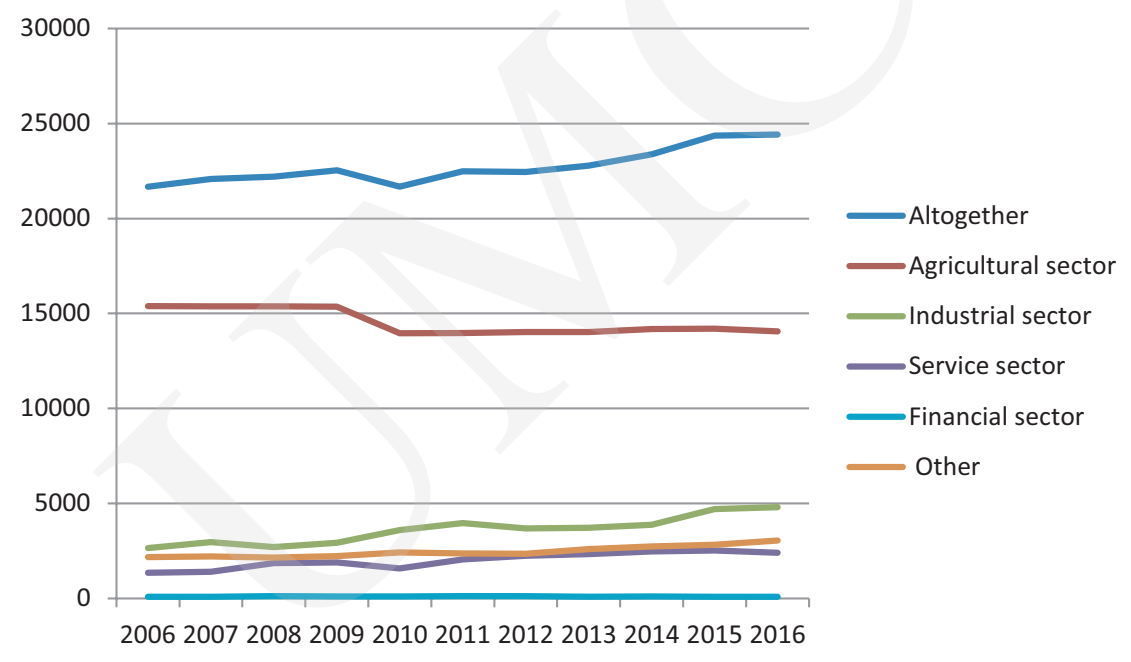

Graph 1. The number of persons employed by economic sectors in the years 2006-2016 in Siedlce County.

Source: GUS, 31 Dec 2016, by: Pracujący według sektorów ekonomicznych w powiecie siedleckim, www.polskawliczbach.pl/powiat_siedlecki [accessed on 17.05.2019].

In the Siedlce County there are more than 20 thousand people employed (the blue line on the graph). This figure is slightly growing year by year. The number of people employed in the agricultural sector is marked in red (or light brown). There are about 15 thousand $(60.7 \%)$ of them, and the slight decrease in the number occurred at the turn of 2009 and 2010. In other sectors: industry - green line (16.6\%), services - purpleline (8.6\%), finance - light blueline (8.6\%), and other - orange line (11.7\%)),

3 The data form GUS, 31 XII 2018: Liczba i płeć mieszkańców powiatu siedleckiego, in: www.polskawliczbach.pl/powiat_siedlecki [accessed on 18.05.2019].

4 The city of Siedlce has about 75 thousand inhabitants. Prior to the administrative reform of 1999 , it was the seat of Siedlce Voivodeship. 
2000-3000 thousand people work in each. ${ }^{5}$ Siedlce County is therefore an agricultural county, and not a very industrialised one.

Agricultural workers account for over $60 \%$ of the total working population of the county.Agricultural landscover about $77.5 \%$ of the area of the county, and forests about $18 \%$. Arable land accounts for $70.8 \%$ of the agricultural land, $24.7 \%$ - meadows and pastures, about $0.8 \%$ - orchards, and about 3.6 - other agricultural lands.Good soils (class II-III) account for $17.7 \%$ of the area of agricultural land, medium soils (class IV) $-43.6 \%$, weak soils (class V-VI) - 38.7\%.There are about 15 thousand farms in the county. Their average size is 9 ha, the area of as many as $40 \%$ of all farms does not exceed 5 ha. Farms with an area of 5-10 ha account for about 30\%, 10-20 ha $-20 \%$, and over 20 ha $-5 \%{ }^{6}$

The determinants of the agricultural structure is a remnant of the agricultural reform of 1946 and the previous political system. During the times of socialism, Polish peasants retained their private property, their farms, however, were very small and did not make it possible to make a living of agriculture. They worked in other sectors (industry, construction, transport, processing, services), which was in line with the intentions of then-governmental authorities that sought collectivization of agriculture and wanted the peasants to give away (or sell) their land to the State Agricultural Farms. After 1989, when Polish economy was reorganised, many farmers lost their additional jobs. They were only left with their small farms.

Small farms (up to 5 ha large) and quite poor soils do not provide a guarantee that one would make a living out of them.Most of the rural residents in the Siedlce County still cannot manage to provide for themselves based on land possession and work in agriculture, fruit farming, horticulture, breeding, etc. This type of activity may be prosperous only to those who own bigger farms or who have focused on specialized production (e.g. asparagus) if the prosperity of these products is maintained.

\section{Characterisation of social problems in Siedlce County}

Identification of social problems and threats in Siedlce County was possible owing to studies carried out by municipal social welfare centres in the county. In the years 2007-2009, 13 municipal social welfare centres conducted research to identify social problems and people benefiting from social welfare in statistical terms.

When analysing the results of these studies, it is important to note that the predominant social problems in Siedlce County are: poverty, unemployment, alcoholism, long or severe illness and disability, the need to protect motherhood, helplessness in welfare and education matters and domestic violence.

5 GUS, 31 XII 2016, by: Pracujący według sektorów ekonomicznych w powiecie siedleckim, www. polskawliczbach.pl/powiat_siedlecki [accessed on 17.05.2019].

6 Powiatowe Centrum Pomocy Rodzinie w Siedlcach, Powiatowa strategia rozwiązywania problemów społecznych na lata 2011-2020, Siedlce 2011, s. 7. This Strategy was an attached no 1 to the Act of Siedlce Country Council No X/53/2011. 
In subsequent years, especially since 2014, there have been further statistical and survey studies conducted. However, the pace of these studies is very slow and they have not been coordinated yet, as it was in 2007-2009, which means that every municipality conducts these studies on its own. Naturally, they confirm previous results ${ }^{7}$ with some numerical changes in the occurrence of particular problems. Drug addiction is being mentioned as a problem more and more often, yet it was not mentioned in previous studies. However, these are still isolated cases and the phenomenon of drug addiction includes the use of all psychotropic substances, both heavy drugs like cocaine, and the so-called 'legal highs'.

These problems and threats can be classified as human-generated.It is also worth noting here that in recent years, there have been more and more environmental (ecological) threats in Poland (including Siedlce County). Oftenlong droughts are experienced in summer, hindering optimal harvest. There are hurricanes, whirlwinds or heavy storms that locally cause enormous damage. But it is probably the nature of our times, the natural threats that we cannot deal with.

The northern communesin the county where the large BugRiverruns are periodically subjected to flooding, although in the recent years no floods have been recorded; instead, there has been a constant decrease in the water level of the BugRiver.

\section{Social threats occurring in Siedlce County}

In this article there is no room for discussing all the social problems and threats. Therefore, I will focus only on the selected ones. The main social threat and problem is the persistent unemployment. The graph shows the unemployment rate in the county in relation to the Masovian Voivodeship and to Poland - as of 2004-2016, according to GUS data.

\footnotetext{
It is also worth noting here that the same results - the definition of social problems in Siedlce County can be found in dissertations prepared by the students of the Siedlce University of Natural Sciences and Humanities, e.g. family problems of people benefiting from social welfare centres, a bachelor's degree thesis by Olga Gołębiewska, under the supervision of UPH professor Janina Florczykiewicz, PhD, Siedlce 2015; Threats to social security in Siedlce in the light of the opinion of national security students, a master's degree thesis written by Karolina Piechowicz, under the supervision of Renata Tarasiuk, PhD, Siedlce 2016; Municipal Social Welfare Centre as a unit serving to solve social problems of inhabitants of the Mordy municipality, a master's degree thesis written by AnetaSiemieńczuk under the supervision of UPH professor Jerzy Kolarzowski, PhD, Siedlce 2016; Activity of the Social Welfare Centre in Wojcieszkowo, a master's degree thesis written by Dorota Kopyść under the supervision of UPH professor Anna Klim-Klimaszewska, PhD, Siedlce 2015.
} 
Pobrane z czasopisma Wschód Europy http://journals.umcs.pl/we

Data: 26/04/2023 13:37:50

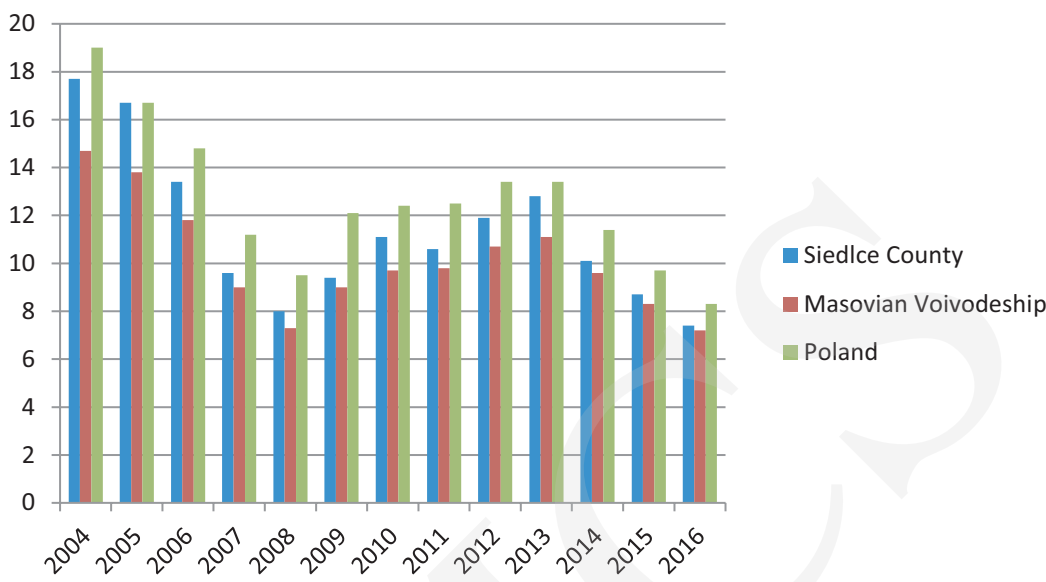

Graph 2. The Unemployment rate in the Siedlce county in relation to the Masovian Voivodeship and to Poland - as of 2004-2016.

Source: GUS, 31 Dec 2016, by: Pracujący według sektorów ekonomicznych w powiecie siedleckim, www.polskawliczbach.pl/powiat_siedlecki [accessed on 17.05.2019].

The data shows that unemployment in the county is constantly falling. In 2004, it was $17.7 \%$, in $2016-7.4 \%$. It is also evident that unemployment in the county is higher than the average for the Masovian Voivodeship, and lower than the national average.

The next two graphs show a chart of unemployment among women and among men. The trends are similar.

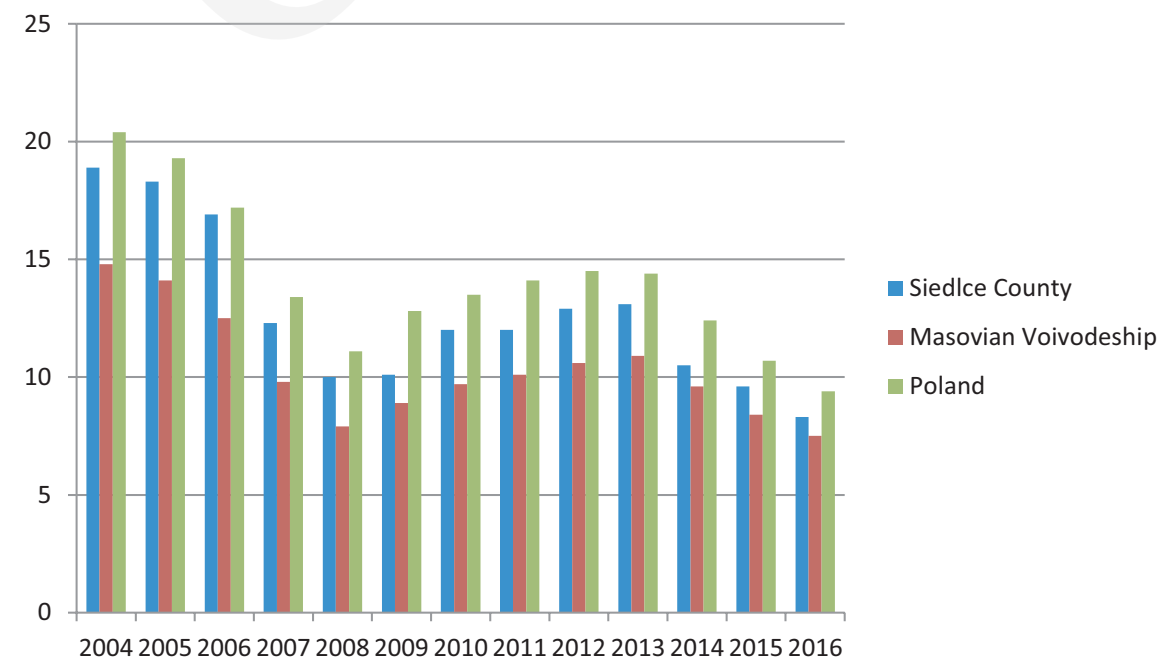

Graph 3. The Unemployment in the Siedlce county among women in the years 2004-2016.

Source: GUS, 31 Dec 2016, by: Pracujący według sektorów ekonomicznych w powiecie siedleckim, www.polskawliczbach.pl/powiat_siedlecki [accessed on 17.05.2019]. 


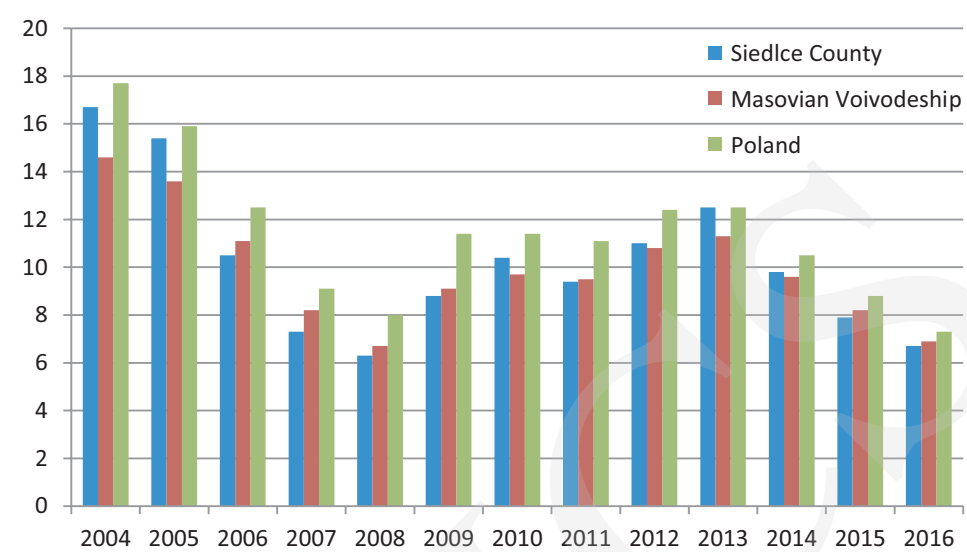

Graph 4. The Unemployment in the Siedlce county among men in the years 2004-2016. Source: GUS, 31 Dec 2016, by: Pracujący według sektorów ekonomicznych w powiecie siedleckim, www.polskawliczbach.pl/powiat_siedlecki [accessed on 17.05.2019].

Based on this data, we can say that the unemployment in Siedlce County is dawning from the year 2013. Nonetheless, this problem requires to be addressed from a broader perspective. Siedlce County has a growing offer in the labour market, yet it covers least paid jobs with little responsibilities, such as a supermarket clerk, a warehouse employee, a simple construction site worker, etc. There are few vacancies in managerial positions, in administration, in various workplaces in Siedlce County. This situation means that a high number of young people, e.g. secondary school graduates, do not decide to continue their education, but think about going abroad to other countries instead. This phenomenon is also observed in the college graduate community. This can be dangerous for the local community, as there is no development of own staff capable of pushing forward the industrial development in the region. ${ }^{8}$

\section{Domestic violence}

One of the social problems is the phenomenon of domestic violence. Domestic violence is an important social problem, hidden and unaddressed for many years. According to legal provisions, domestic violence can be defined as all incidents of threats, violence or harassment (be it psychological, physical, sexual, economic or emotional) between members of family, regardless of sex (gender) and sexual orientation. ${ }^{9}$

8 These conclusions come from the author's many years of work with the student community at the University of Siedlce and the community of secondary schools in Siedlce County.

9 The Act of 29 July 2005 on the prevention of domestic violence (Journal of Laws of 2015, item 1390), in art. 2 points 2. On the basis of the definition in the Act on Family Violence, it means: "all incidents of threats, violence or harassment (psychological, physical, sexual, economic or emotional) between persons who live in a relationship with members of the same family, regardless of gender and orientation sexual." 
Domestic violence usually takes on the form of physical violence, that is, beating. However, this is not the only form. There is also active and passive physical violence, economic, psychological (emotional) and sexual violence, and neglect.

Domestic violence is one of most serious threats occurring in families. It is carried out by one family member towards other member(s). Consequently, the family ceases to serve as a place of peace, love and safety. Instead of being a safe haven, the family home becomes a place of threats.

The causes of domestic violence lie primarily in alcoholism and the lack of life perspectives - e.g. in long-term unemployment which leads to poverty and searching for an escape in having "a drink". However, according to the data of social care centres, we cannot claim domestic violence to be applied solely by individuals in a state of alcoholic intoxication and the unemployed. Domestic violence is used regardless of people's economic, social or professional status.

The consequences of domestic violence are short and long term. We classify these as follows:

- adaptation disorder

- mental disorder including personality disorder

- psychosomatic disorder

- injuries

- death on account of injuries

- organic disorder of brain

- suicides

- problems with education

- addictions

- family breakdown. ${ }^{10}$

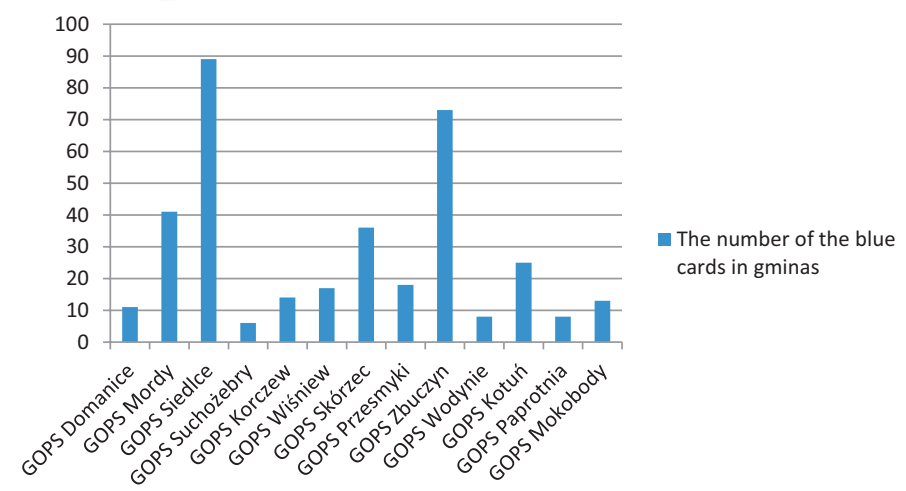

Graph 5. The number of the blue cards in the communes of Siedlce County in the years 2013-2014. Domestic violence.

Source: Annex to Resolution No. XII/77/2015 of the County Council in Siedlce of 30 October 2015: Powiatowy Program Przeciwdziałania Przemocy w Rodzinie oraz Ochrony Ofiar Przemocy w Rodzinie na lata 2015-2020, p. 12

10 A. Bakuła, Przemoc w rodzinie, brok.edu.pl. 
On the next graph we have shown the numbers of interventions in the communes of Siedlce county in the years 2013-2014.

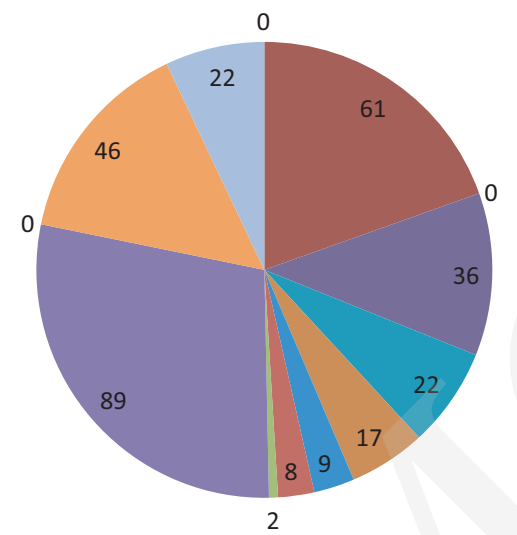

$$
\begin{aligned}
& \text { - GOPS Mokobody } \\
& \text { - GOPS Zbuczyn } \\
& \text { GOPS Wodynie } \\
& \text { - GOPS Skórzec } \\
& \text { - GOPS Suchożebry } \\
& \text { - GOPS Wiśniew } \\
& \text { - GOPS Korczew } \\
& \text { - GOPS Domanice } \\
& \text { - GOPS Mordy } \\
& \text { GOPS Siedlce } \\
& \text { - GOPS Paprotnia }
\end{aligned}
$$

Graph 6.The number of crisis intervention in the communes of Siedlce county in the years 2013-2014.

Source: Annex to Resolution No. XII/77/2015 of the County Council in Siedlce of 30 October 2015: Powiatowy Program Przeciwdziałania Przemocy w Rodzinie oraz Ochrony Ofiar Przemocy w Rodzinie na lata 2015-2020, p. 11.

Legend: GOPS - Commune Family Support Centre

And we also obtained some data from the Police Headquarters in Siedlce on the home interventions regarding domestic violence in the years 2013-2015.

Table 1.The home interventions regarding domestic violence of Siedlce county in the years 2013-2015.

\begin{tabular}{|c|c|c|c|c|c|c|c|c|c|}
\hline \multirow{2}{*}{ Year } & \multirow{2}{*}{$\begin{array}{c}\text { Number of } \\
\text { interventions }\end{array}$} & \multicolumn{4}{|c|}{ Number of victims } & \multicolumn{4}{c|}{ Number of perpetrators } \\
\cline { 3 - 10 } & & Total & Women & Men & Children & Total & Women & Men & Inebriated \\
\hline 2013 & 101 & 346 & & & & 244 & 9 & 235 & 91 \\
\hline 2014 & 191 & 457 & & & & 355 & 14 & 341 & 180 \\
\hline 2015 & 158 & 198 & 139 & 19 & 9 & 158 & 1 & 157 & 76 \\
\hline
\end{tabular}

Source:Annex to Resolution No. XII/77/2015 of the County Council in Siedlce of 30 October 2015: Powiatowy Program Przeciwdziałania Przemocy w Rodzinie oraz Ochrony Ofiar Przemocy w Rodzinie na lata 2015-2020, p. 11; Data from the Police Headquarters in Siedlce.

The above data do nottake into account all the victims and perpetrators. We do not have the exhaustive knowledge of all the cases of domestic violence.

The fight against domestic violence consists in large part of correcting and educatingby means of programs used by the County Family Support Centre and other help centres:

- Interdisciplinary Teams in the communes 
- Social Support Centres

- City Police Headquarters

- Police stations

- Municipal Commission for Alcohol Problem Solving

- Health Care Facilities

- County Court in Siedlce

- County and Regional Prosecutor's Office in Siedlce

- Municipal and County self-government

- Non-governmental organizations

The programs are targeted at adults who have committedacts of domestic violence or have been convicted of such an act - their participation in the program is intended to be one of the elements of social rehabilitation;they also involve victims of domestic violence and other individuals who want to participate in the program.

Nonetheless, the biggest problem in fighting domestic violence is the resistance of victims against the disclosure of such fact and acting against their close ones. It comes from a great sense of shame and fear of the consequences from the perpetrators. Feelings for the close ones who use violence are important. At first, victims forgive the perpetrators for using violence and then they fall into a state of intimidation or disbelief that anything could help.

The aims of the programs are: 1 . to increase social consciousness and change stereotypes in the matter of domestic violence; 2 . to facilitate access to guidance and support for victims of violence; 3.to reducethe number of cases where violence is applied.

These aims are implemented by means of organizing information campaigns, educating local communities in the matter of domestic violence, organizing classes on violence prevention in school and social centers (aim 1); organizing the consulting-intervention stage, providing psychological and legal guidance for victims, organizing therapies for victims (aim2); offering rehabilitation and educational programs for perpetrators, providing psychological guidance for perpetrators, organizing therapies for perpetrators. ${ }^{11}$

\section{Foster families}

Another social problem is the issue of children who have no conditions for proper development. These are children from pathological families that fail to provide proper childcare. One way to secure the future of such children and help them is to put them in foster families, which is a better solution than an orphanage or other centres providing the care of minors. The change of the immediate family environment is intended to help counter the transfer of bad patterns from biological parents through children.

11 Annex to Resolution No. XII/77/2015 of the County Council in Siedlce of 30 October 2015: Powiatowy Program Przeciwdziałania Przemocy w Rodzinie oraz Ochrony Ofiar Przemocy w Rodzinie na lata 2015-2020, pp. 15-17. 
Table 2. The number of families who fail to provide care and fulfil the educational function correctly and the number of children at risk of being placed in foster care from the area of Siedlce County in 2013-2016.

\begin{tabular}{|c|c|c|c|c|c|c|c|c|}
\hline \multirow[t]{2}{*}{ Commune } & \multicolumn{4}{|c|}{$\begin{array}{l}\text { The number of families who fail to } \\
\text { provide care and fulfil the educational } \\
\text { function correctly }\end{array}$} & \multicolumn{4}{|c|}{$\begin{array}{l}\text { The number of children at risk of being } \\
\text { placed in foster care }\end{array}$} \\
\hline & 2013 & 2014 & 2015 & 2016 & 2013 & 2014 & 2015 & 2016 \\
\hline Domanice & 8 & 10 & 10 & 10 & 3 & 5 & 5 & 3 \\
\hline Korczew & 5 & 5 & 5 & 5 & 1 & 1 & 1 & 1 \\
\hline Kotuń & 145 & 134 & 147 & 133 & 306 & 242 & 203 & 246 \\
\hline Mokobody & 9 & 9 & 9 & 9 & 0 & 0 & 0 & 0 \\
\hline Mordy & 14 & 14 & 14 & 12 & 42 & 42 & 42 & 11 \\
\hline Paprotnia & 5 & 5 & 5 & 5 & 1 & 1 & 1 & 1 \\
\hline Przesmyki & 9 & 9 & 12 & 12 & 19 & 19 & 25 & 25 \\
\hline Siedlce & 14 & 14 & 14 & 18 & 6 & 6 & 6 & 8 \\
\hline Skórzec & 30 & 30 & 30 & 30 & 0 & 0 & 0 & 0 \\
\hline Suchożebry & 2 & 2 & 2 & 2 & 3 & 3 & 3 & 3 \\
\hline Wiśniew & 10 & 10 & 10 & 9 & 3 & 3 & 3 & 3 \\
\hline Wodynie & 12 & 12 & 12 & 13 & 7 & 7 & 7 & 4 \\
\hline Zbuczyn & 6 & 6 & 6 & 6 & 16 & 16 & 16 & 16 \\
\hline TOTAL & 269 & 260 & 276 & 264 & 407 & 345 & 312 & 321 \\
\hline
\end{tabular}

Source: Annex to Resolution No. XXV/150/2017 of the CountyCouncil in Siedlce of 24 February 2017: Powiatowy program pieczy zastępczej w powiecie siedleckim na lata 2017-2019, Siedlce, February 2017, p. 8.

The number of families failing to provide care and fulfil their educational function correctly in Siedlce County in 2013-2016 remained at a similar level.

The highest number of family backgrounds showing difficulties in fulfilling their functions was recorded by the Municipal Social Welfare Centre in Kotun, whereas the lowest - by the Municipal Social Welfare Centre in Suchożebry. In the period of 20132016, the number of children at risk of being placed in foster care fell from 407 in 2013 to 321 in 2016.

Social welfare centres indicated the main causes of children being at risk of being placed in foster care:

- parental inefficiency of biological parents,

- addiction, particularly problems with alcohol consumption,

- domestic violence,

- helplessness in care and educational matters,

- at least one of the parents living abroad,

- disability,

- parents' emotional immaturity.

In Poland, there are 4 types of foster family care: related foster families, professional foster families, family orphanages, non-professional foster families. 
- related foster family - is a foster family formed by spouses or an unmarried person who is an ascendant (relative, cognate) or a sibling of the child;

- non-professional foster family - is a foster family formed by spouses or an unmarried person who is not an ascendant or a sibling of the child;

- professional foster family - a foster family, including a professional specialized foster family and a professional foster family acting as family emergency. Professional families can take not more than 3 children, in particularly justified cases, and with the consent of foster parents, it is permissible to place more children. Professional specialized foster family accepts especially children with (significant or moderate) disabilities. Professional families receive monthly remuneration for childcare;

- family orphanage - formed by spouses or an unmarried person, taking care of a total of no more than 8 children and persons who have reached the age of majority while being in foster care.

Table 3. The number of foster families and children placed there in Siedlce County in 2013-2016

\begin{tabular}{|l|c|c|c|c|c|c|c|c|}
\hline \multirow{2}{*}{$\begin{array}{c}\text { Type of foster } \\
\text { family }\end{array}$} & \multicolumn{2}{|c|}{2013} & \multicolumn{2}{c|}{2014} & \multicolumn{2}{c|}{2015} & \multicolumn{2}{c|}{2016} \\
\cline { 2 - 9 } & $\begin{array}{c}\text { number } \\
\text { of } \\
\text { families }\end{array}$ & $\begin{array}{c}\text { number } \\
\text { of } \\
\text { children }\end{array}$ & $\begin{array}{c}\text { number } \\
\text { of } \\
\text { families }\end{array}$ & $\begin{array}{c}\text { number } \\
\text { of } \\
\text { children }\end{array}$ & $\begin{array}{c}\text { number } \\
\text { of } \\
\text { families }\end{array}$ & $\begin{array}{c}\text { number } \\
\text { of } \\
\text { children }\end{array}$ & $\begin{array}{c}\text { number } \\
\text { of } \\
\text { families }\end{array}$ & $\begin{array}{c}\text { number } \\
\text { of } \\
\text { children }\end{array}$ \\
\hline Related to children & 31 & 44 & 31 & 44 & 33 & 44 & 34 & 45 \\
\hline Non-professional & 11 & 16 & 12 & 15 & 12 & 14 & 12 & 14 \\
\hline Professional & 1 & 1 & 2 & 4 & 3 & 7 & 3 & 8 \\
\hline
\end{tabular}

Source: Annex to Resolution No. XXV/150/2017 of the County Council in Siedlce of 24 February 2017: Powiatowy program pieczy zastępczej w powiecie siedleckim na lata 2017-2019, Siedlce, February 2017, p. 8.

Siedlce County does not have many families or orphanages and other centres such as children's village (there is only one). There are very few professional families the three whose receive remuneration for childcare. Families related to the child are the most common - there are over 30, then non-professional families - over ten, and only 3 professional families. According to specialists (family court judges, social workers), the county has too few families and places in children's village compared to the needs. In addition, they also point out that the existing foster families are usually quite far from the place of residence of the child's family that they are taken from. According to them, child should be placed close to their biological family, so that both the child and their parents can keep in touch. Placing children in foster families should not mean taking them away from their parentsbut giving them and their parents a chance to improve the situation in the family and for the child to return to their parents. ${ }^{12}$

12 Conclusions based on the accounts of judges of the County Court in Siedlce, Family Division: Agnieszka Chomiuk-Indraszczyk, Jarosław Makuła, Jolanta Warsz. 
The small number of foster families may be caused by the low social awareness about the need for such families, as well as the small material resources that these families receive for the child. ${ }^{13}$

The Siedlce County has only one operating education and care facility of nature socializing nature - Dom na Zielonym Wzgórzu (The House on Green Hill) in Kisielany. The facility has 30 places for children partially or completely deprived of care from their biological families. The statutory tasks of an education and care facility include:

- to provide 24-hour care and education to children and meet their essential needs, in particular those relating to emotional and physical health, development, standard of living, social life and religion;

- implementation of a child support plan prepared in cooperation with a family assistant;

- enabling contacts of the child with their parents and other close ones, unless the court has decided otherwise;

- taking action aimed at child's return to the family;

- providing the child with access to education appropriate to their age and development opportunities;

- providing the child therapeutic activities;

- ensuring the use of health benefits. ${ }^{14}$

Table 4. The number of children staying in "Dom na Zielonym Wzgórzu" in Kisielany in $2013-2016$ by age of children.

\begin{tabular}{|l|r|r|r|r|}
\hline \multirow{2}{*}{ Age of children in } & \multicolumn{4}{|c|}{ The number of children } \\
\cline { 2 - 5 } & 2013 & 2014 & 2015 & 2016 \\
\hline $2-5$ & 0 & 0 & 0 & 2 \\
\hline $7-10$ & 3 & 2 & 2 & 3 \\
\hline $11-14$ & 8 & 12 & 14 & 9 \\
\hline $15-18$ & 17 & 15 & 16 & 15 \\
\hline $19-21$ & 0 & 1 & 1 & 2 \\
\hline Total & 28 & 30 & 33 & 31 \\
\hline
\end{tabular}

Source: Annex to Resolution No. XXV/150/2017 of the County Council in Siedlce of 24 February 2017: Powiatowy program pieczy zastępczej w powiecie siedleckim na lata 2017-2019, Siedlce, February 2017, p. 19.

13 "A foster family, for each placed child, is entitled to a benefit to pay their living costs, not lower than the amount of PLN 1,660 per month - for a child placed in a related foster family; PLN 2,1000 per month - for a child placed in a professional foster family, non-professional foster family or family orphanage", Annex to the Resolution No. XXV/150/2017 of the County Council in Siedlce of 24 February 2017: Powiatowy program pieczy zastępczej w powiecie siedleckim na lata 2017-2019, Siedlce, February 2017, p. 11.

14 These tasks result from Article 93 of the Act of 9 June 2011r. on supporting the family the foster care system (Journal of Laws 2016 item 575, as amended). 
It should be noted that children placed in "Dom na Zielonym Wzgórzu" in Kisielany did not come from Siedlce County only (although, it was the most numerous group), but also from the city of Siedlce and the neighbouring counties. What is more, children from Siedlce County in 2013-2016 stayed in similar institutions in the city of Siedlce and other counties. They were 41 children of different age groups. ${ }^{15}$

Preventing children from copying bad behavioural patterns and enabling better conditions for children does not end with the act of transferring a child to a foster family. Foster families, children and their biological parents attend meetings and conversations to help them find themselves in the new situation, understand the purpose of changes and make it possible for the child to return to biological parents.

\section{Demographics and education}

Siedlce County has a positive natural increase rate of 23 . This corresponds to a natural increase of 0.3 per 1,000 inhabitants of Siedlce County. In 2015, 867 children were born, including $48.8 \%$ girls and $51.2 \%$ boys. The demographic dynamics ratio, i.e. the ratio of the number of live births to the number of deaths, is 1.03 and is comparable to the average of the voivodship and is higher than the demographic dynamics ration for the whole country.

However, according to GUS calculations, the number of inhabitants of the county will decrease in $2017-2050$.

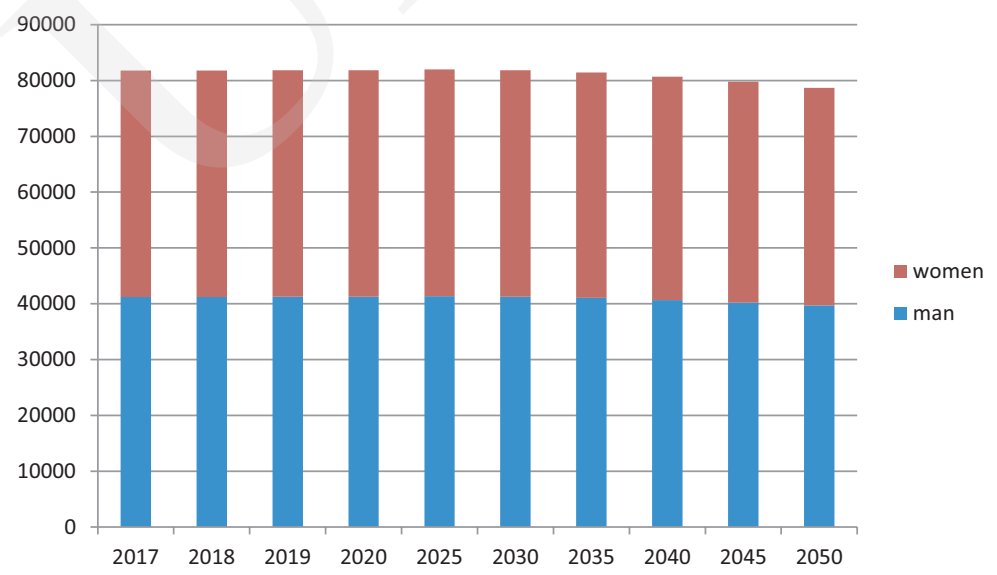

Graph 7.Projected population - Siedlce County in 2017-2050.

Source: GUS, 31 XII 2018, by: Prognozowana liczba mieszkańców powiatu siedleckiego w latach 2017-2050, www.polskawliczbach.pl/powiat_siedlecki [accessed on 18.05.2019].

15 Annex to the Resolution No. XXV/150/2017 of the County Council in Siedlce of 24 February 2017: Powiatowy program pieczy zastępczej w powiecie siedleckim na lata 2017-2019, Siedlce, February 2017, p. 20. 
In 2050, the number of women is supposed to be 39,002 (49.6\%), and men - 39,681 (50.4\%). The total population of the county is estimated to be 78,683 , that is, 2,766 less than the current number of 81,449 . This is not perhaps the biggest decrease in the population number, but given the risk of outflow of young people that we observe, this decrease may be more substantial.

The chart below shows the level of education in the Siedlce Country - in the city and in the countryside.

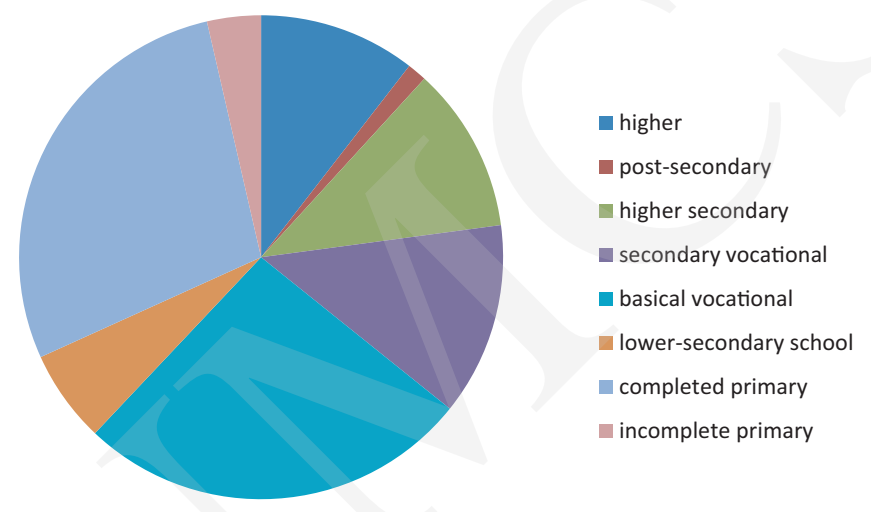

Graph 8.The level of education in the Siedlce Country - in the city and in the countryside.

Source: National Census GUS, 2011,by: https://stat.gov.pl/spisy-powszechne/nsp-2011/nsp2011-wyniki/ [accessed on 18.05.2019].

We can see that in rural areas, we have a higher percentage of people with lowest levels of education, and a lower percentage of the higher education levels. However, the differences are not that significant, in particularwhen it comes to higher, post-secondary, and higher-secondary education.

The increasing level of education should have a positive impact on social problems and threats in the county. Nonetheless, it also causes another threatin the form of the outflow of educated people from the county.

Based on interviews with students during my seminars(bachelor's and master's degree), I can say that young people in secondary and tertiary education consider the biggest social threat to be the lack of good prospects for life in the region. They point to the issue of unemployment, the difficulty of finding a job, and the issue of underpaid jobs. They believe that there are basically no interesting well-paid job offers in the county (including the city of Siedlce) for graduates. Such situation is the reason that educated young people seek other places to live, in the country, in Europe, and less often - in the world. More and more undergraduates decide to discontinue their studies and go abroad in search of better paid jobs (better, of course, in comparison to the Polish realities). The issue of continuing studies in Poland or abroad recedes into the background and does not seem important to them. Education in the field of social sciences and the 
humanities does not guarantee them jobs and decent earning. This way, the idea of studying loses its meaning for them. More and more often one can encounter opinions that studying is only a waste of time that leaves the graduate struggling for getting an underpaid job in services industry (cleaning, trade, etc.) in the West or in Poland, and the Siedlce region is too small and cannot absorb university graduates.

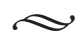

\begin{abstract}
The article presents a description of selected social threats in Siedlce County, particularly unemployment, domestic violence, necessaries of children care, lower education level. At the end of the article, former social threats are compared with the current ones that have appeared at the beginning of the $21^{\text {st }}$ century. Probably the biggest social threat in the county is the low level of high technologies and the demand for low services. This means that despite the fact that unemployment is falling, and even in most industries there is a lack of employees, due to low attractiveness of offers on the labour market young people are thinking about leaving the county.
\end{abstract}

Keywords: Siedlce County, social problems, social threats.

\title{
Problemy społeczne i zagrożenia w powiecie siedleckim na początku XXI wieku
}

Streszczenie: W artykule opisano wybrane zagrożenia społeczne powiatu siedleckiego, bezrobocie specjalistyczne, przemoc domową, konieczność opieki nad dziećmi, niższy poziom wykształcenia. Na końcu artykułu porównano stare zagrożenia społeczne z nowymi, które pojawiły się na początku XXI wieku. Prawdopodobnie największym zagrożeniem społecznym w powiecie jest niski poziom wysokich technologii i popyt na niskie usługi. Oznacza to, że pomimo spadku bezrobocia w większości branż brakuje pracowników, jednak ponieważ oferta pracy nie jest zbyt atrakcyjna, młodzi ludzie myślą o opuszczeniu powiatu.

Słowa kluczowe: powiat siedlecki, problemy społeczne, zagrożenia społeczne.

\section{Социальные проблемы и угрозы в Седльском районе в начале XXI века}

Аннотация: В статье описываются отдельные социальные угрозы для Седльского района, специализированная безработица, насилие в семье, необходимость ухода за детьми, низкий уровень образования. В конце статьи старые социальные угрозы сравниваются с новыми, появившимися в начале XXI века. Вероятно, самая большая социальная угроза в поветах это низкий уровень высоких технологий и спрос на низкие услуги. Это означает, что, несмотря на снижение уровня безработицы, и даже в большинстве отраслей, наблюдается нехватка работников, но поскольку предложение о работе не очень привлекательно, молодые люди думают о том, чтобы покинуть повет.

Ключевые слова: Седльский район, социальные проблемы, социальные угрозы. 
Pobrane z czasopisma Wschód Europy http://journals.umcs.pl/we

Data: 26/04/2023 13:37:50

172

Arkadiusz Indraszczyk

\section{Bibliography}

Annex to Resolution No. XII/77/2015 of the County Council in Siedlce of 30 October 2015: Powiatowy Program Przeciwdziałania Przemocy w Rodzinie oraz Ochrony Ofiar Przemocy w Rodzinie na lata 2015-2020.

Annex to the Resolution No. XXV/150/2017 of the County Council in Siedlce of 24 February 2017: Powiatowy program pieczy zastępczej w powiecie siedleckim na lata 2017-2019, Siedlce, February 2017.

Article 93 of the Act of 9 June 2011r. on supporting the family the foster care system (Journal of Laws 2016 item 575, as amended).

Bakuła A., Przemoc w rodzinie, brok.edu.pl.

GUS, 31 XII 2016, by: Pracujący według sektorów ekonomicznych w powiecie siedleckim, www.polskawliczbach.pl/powiat_siedlecki [accessed on 17.05.2019].

Liczba i płeć mieszkańców powiatu siedleckiego, in: www.polskawliczbach.pl/powiat_siedlecki [accessed on 18.05.2019].

Powiatowe Centrum Pomocy Rodzinie w Siedlcach, Powiatowa strategia rozwiązywania problemów spotecznych na lata 2011-2020, Siedlce 2011.

Social debate in Zbuczyn, http://www.podlasie24.pl/powiat-siedlecki/region/debata--spoleczna--wzbuczynie-2177c.html [accessed on 21.08.2017].

The geodetic area of the county is 160,322 ha according to EwidencjaGruntówiBudynkówWydziałuGeodezjiiGospodarkiNieruchomościamiStarostwa, after: Characterisation of the county, [in:] https:/l www.powiatsiedlecki.pl/charakterystyka-powiatu/ [accessed on 21.08.2017]. 